\title{
POLIMER ANYAGOK LÉZERSUGARAS JELÖLHETŐSÉGE
}

\section{LASER MARKABILITY OF POLYMER CABLE INSULATIONS}

\author{
Dobránszky János $^{1}$, Bitay Enikö ${ }^{2}$ \\ ${ }^{1}$ MTA-BME Kompozittechnológiai Kutatócsoport, 1111 Budapest, Müegyetem rak- \\ part 3. Magyarország, telefon: +3614631934,Dobranszky.Janos@eik.bme.hu \\ ${ }^{2}$ Sapientia Erdélyi Magyar Tudományegyetem, Șoseaua Sighișoarei 1C, Corunca \\ 540485, Románia, telefon:+40-75-1016063,ebitay@ms.sapientia.ro
}

\begin{abstract}
The paper presents laser marking experiments that were carried out on many, different colour, automotive cable insulation for determining their ability to laser marking. It was studied that how deep is the degradation caused by the laser beam, compared to the insulation thickness. Yellow, red, green and black colour insulations were marked by using a TRUMPF VectorMarc workstation, than investigated by preparing cross-sectional metallographic samples. Minimal and maximal value of the laser affected depth was 32 and 159 microns for the green and the yellow colour insulation respectively.
\end{abstract}

Keywords: laser markability, laser marking, polymer insulation, marking depth

\section{Összefoglalás}

A cikk azokat a kísérleteket ismerteti, amelyeket a szerzők annak érdekében végeztek, hogy meghatározzák többféle autóvillamossági kábel eltérő színü szigetelésének lézerrel való jelölhetőségét. A jelölhetőséget annak alapján értékelték, hogy milyen, az eredeti vastagsághoz mért relatív mélységbe hatolt be a lézersugár a polimer anyag roncsolódását okozva. A sárga, piros, zöld és fekete színủ kábelszigetelések a TRUMPF VectorMarc munkaállomáson készített jelölések után metallográfiai keresztcsiszolatukon voltak vizsgálva.

Kulcsszavak: lézeres jelölhetőség, lézeres jelölés, polimer szigetelés, jelölési mélység

\section{Bevezetés}

A müanyagok lézersugaras jelölése talán a leginkább elterjedt lézersugaras megmunkálás. A jelölés része a tömeggyártásnak, ahol gyakran szabad szemmel nem is követhető sebességgel „folyik” a gyártmány a gyártósoron, és ebben a dinamikus folyamatban kell sokszor minden egyes terméket egyedi azonosítóval ellátni $[1,2,3]$.

A jelölés hatásmechanizmusát tekintve lehet gravírozás, ablálás, hőkezelés, habosítás és hőszínezés. Az autóipari kábelek szi- geteléseinek jelölésére gyakorlatilag csak a hőszínezés jöhet szóba, mivel minden más jelölési mechanizmus az anyag szerkezetének vagy mennyiségének olyan mértékü változását okozza, amely már zavarná az alapvető rendeltetést $[4,5,6]$.

Természetes, hogy ebben a technológiai környezetben a jelöléssel szemben nemcsak a legalapvetőbb müszaki követelmények fogalmazódnak meg - mint pl. a láthatóság vagy a tartósság -, de a gyorsaság is. A bemutatott kísérletek az eredeti, 0,26 s ciklusidő rövidítése céljával készültek. 
A hőre lágyuló müanyagok lézeres jelölése során különböző kölcsönhatások mennek végbe, és ezek közül néhány nem teljesen ismert. Az teljesen nyilvánvaló, hogy a kölcsönhatás a lézer és az anyag között számos tényezőtőll függ, és a kölcsönhatás eredménye is eltérő. Például a szürke színü PA66 anyagot töltőanyag nélkül is lehetséges jelölni, de a (tüz esetén) önkioltó tulajdonságú PA66-ot talán lehetetlen jelölni.

Annak érdekében, hogy a höre lágyuló polimer anyagokat lehetséges legyen lézerrel megjelölni, alapvető követelmény, hogy az anyag elnyelje a lézersugár által szállított energiát. Ennek hatására az anyag színe megváltozik (vagy hasonló hatás alakul ki). Az abszorpció természetesen megvalósulhat magában a polimer anyagban, de ha mégsem, akkor szükség van színezőanyagok (pigmentek) és/vagy más adalékanyagok hozzáadására.

A legtöbb, hőre lágyuló müanyagot, amely nem pigmentált (tehát színe a polimer anyag eredeti színe), nem lehet jelölni lézerrel, illetve lehet, de a jelölés láthatósága gyenge, mert az anyag nem nyeli el a lézerfényt, amelynek hullámhossza a jelölésben elterjedten használt Nd:YAG lézerforrásnál $1064 \mathrm{~nm}$.

A hőre lágyuló, töltőanyag vagy pigmentek nélküli - ún. természetes höre lágyuló polimerek - három általános kategóriába oszthatók a lézeres jelölésre való alkalmasságuk alapján:

\section{- 1. csoport}

Olyan polimerek, amelyek jól elnyelik a lézersugárzást; ennek következtében elszenesednek (feketednek), amitől jól észrevehetően sötétebb lesz az a terület, ahol a lézersugárzás elnyelődött. Példák az ilyen anyagokra: a poliészterek (PES) és a poliszulfonok (PSU).

\section{- 2. csoport}

Azok a hőre lágyuló polimerek, amelyek kiszámíthatatlanul nyelik el a sugárzást, ezért elszenesedésük szabálytalan, a jelö- lési nyomok tehát nem egységesek, azaz nem folytonos jelölés. Például az ilyen anyagok közé tartoznak a polisztirolok (PS) vagy habosítható kopolimerek közé tartozó sztirol-akrilnitril (SAN) és az akrilnitril-butadién-sztirol (ABS). Ez a 2. csoport magába foglalja a sztirol- és poliészteralapú gyantákat (PET és PBT). Ha megfelelő pigmentet vagy különleges adalékanyagot is tartalmaznak, ezek az anyagok egyenletesebben jelölhetők, és kiváló minőségü jelölést is kaphatunk. Mindkét, eddig említett csoportban optimalizálható egy pigment/adalék keveréke annak érdekében, hogy a sötét háttéren olyan jelölés jöjjön létre, amelynek színe megközelíti a fehéret.

-3. csoport

Olyan, hőre lágyuló mủanyagok, amelyeknek nagyon kicsi vagy akár el is hanyagolható a lézersugár-elnyelésük. Ez a csoport magában foglalja a PA, POM, PP, PE és a PPS polimereket. Az eredeti, színezetlen, állapotában ezeket az anyagokat nem lehet megjelölni lézerrel. Azonban egy világos színü, közel fehér jelölés készíthető sötét színű pigment hozzáadásával. Ezek a hőre lágyuló polimerek tehát a pigment színétől függően világos és sötét színű jelöléssel is elláthatók az adalékanyagok fajtájától függően.

A lézeres jelölést erősen befolyásolják a töltőanyagok, a keménységnövelő erősítők, a különleges adalékok, mint pl. az önkioltó viselkedést biztosító adalékanyagok.

Ellentétben azzal, amit gondolnánk, az üvegszálak jelenléte csak kismértékben csökkenti a (lézeres) jelölhetőséget. Lévén saját színük, bizonyos típusú töltőanyagok vagy önkioltó adalékanyagok csökkenthetik a müanyag alkalmasságát a lézeres jelölésre. Ugyanakkor bizonyos önkioltó rendszerek adalékanyagai javíthatják a lézeres jelölés kontrasztját. 


\section{A kísérleti anyagok és a vizsgá- lathoz használt eszközök}

Az együttmüködő ipari partnerünkkel egyeztetett és előzetesen kísérleti céllal kipróbált szakmai programnak megfelelően elvégeztük a hat különböző autóipari villamos vezeték szigetelésén a lézersugaras jelöléseket, majd az elhelyezett lézersugaras jelölések anyagvizsgálatát.

A jelek TRUMPF VectorMarc VMc 5 típusú munkaállomáson készültek, $55 \mathrm{kHz}$ frekvencia, $5 \mu$ s impulzushossz és $0,05 \mathrm{~mm}$ átfedés alkalmazásával; a ciklusidő $120 \mathrm{~ms}$.

A vizsgálatok célja az volt, hogy meghatározzuk a lézersugár behatolási mélységét, hatását és az esetleges szerkezeti elváltozásokat a szigetelésnek a felület alatti zónájában. A vizsgálatokat a következő színü vezetékeken végeztük:

- sárga,

- piros,

- piros-fekete,

- zöld-sárga,

- fekete-H,

- fekete-R.

A lézeres jelölési kísérletek után a jelölések topográfiai jellemzőit Nikon SMZ-2 típusú sztereobinokuláris mikroszkóppal vizsgáltuk. A huzalok keresztcsiszolatainak optikai mikroszkópos vizsgálatát Olympus PMG-3 fémmikroszkóppal végeztük. A lézersugár behatolási mélységét a mikroszerkezeti fotókon kvantitatív képelemző módszerrel mértük.

\section{A kísérletek eredménye}

\subsection{A sárga színú vezeték vizsgálata}

Az 1. és a 2. ábrán látható a lézersugaras jelölés felületi képe, illetve a keresztcsiszolatról készített kép. A behatolási mélységet a külső szaggatott vonalig terjedö távolság jelenti. A lézersugár szük csatornákon, de viszonylag mélyre hatol be.

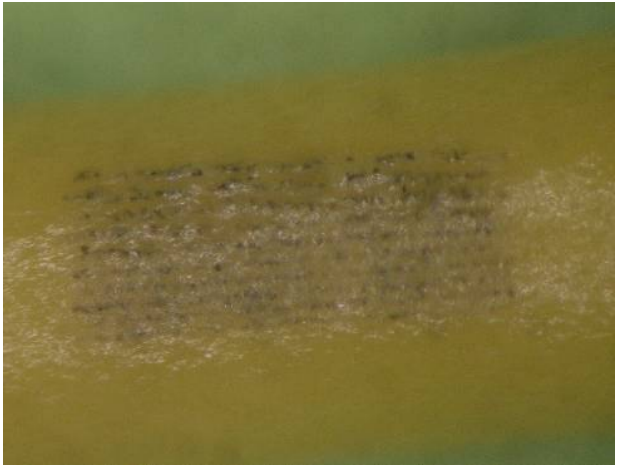

1. ábra. A 2×0,6 mm-es jelölés képe a szigetelés felületén

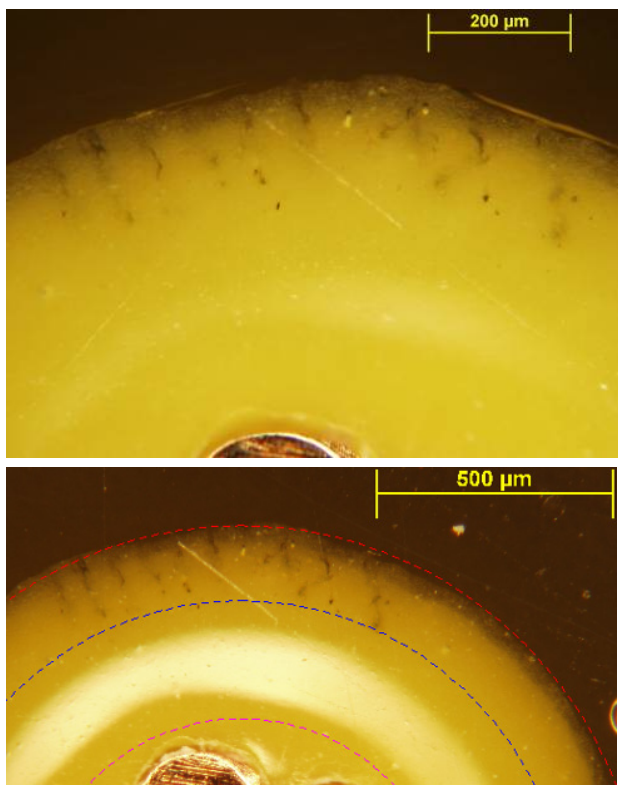

2. ábra. A lézersugár által érintett zóna a keresztcsiszolaton; a behatolási mélység 159 mikrométer

\subsection{A piros színú vezeték vizsgálata}

A 3. és a 4. ábrán látható a lézersugaras jelölés felületi képe, illetve a keresztcsiszolatról készített kép. A behatolási mélységet a 4. ábrán a szaggatott vonalak köze jelöli. A lézersugár széles csatornákon, de viszonylag kis mélységre hatolt be, a felületi kitöltés teljesen egyenletes. 


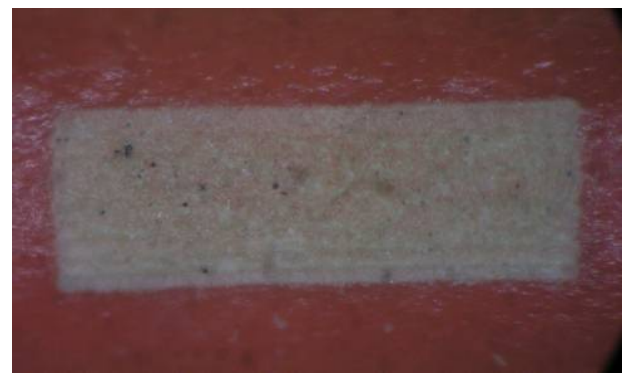

3. ábra. A 2×0,6 mm-es jelölés képe a szigetelés felületén

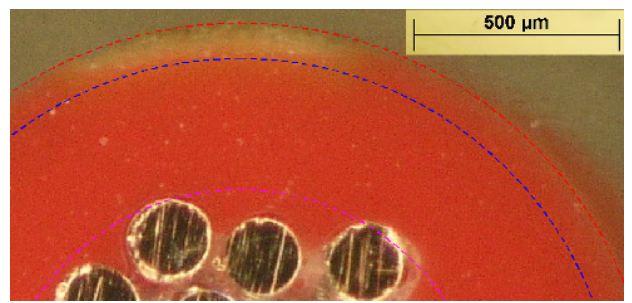

4. ábra. A lézersugár által érintett zóna a keresztcsiszolaton; a behatolási mélység 88 mikrométer

\subsection{A piros-fekete színú vezeték vizsgálata}

Az 5. ábrán látható a lézersugaras jelölés felületi képe, a 6. ábrán pedig a csiszolatról sztereomikroszkóppal készített kép.
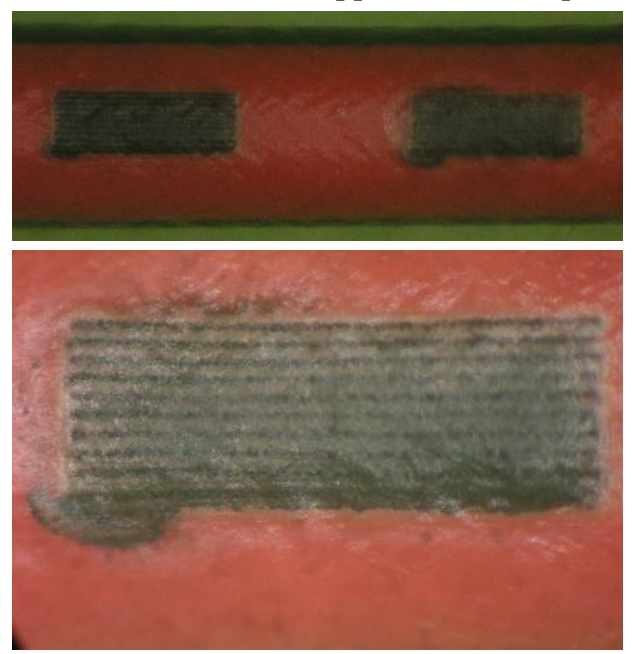

5. ábra. A lézeres jelölés a piros színü anyag felületén
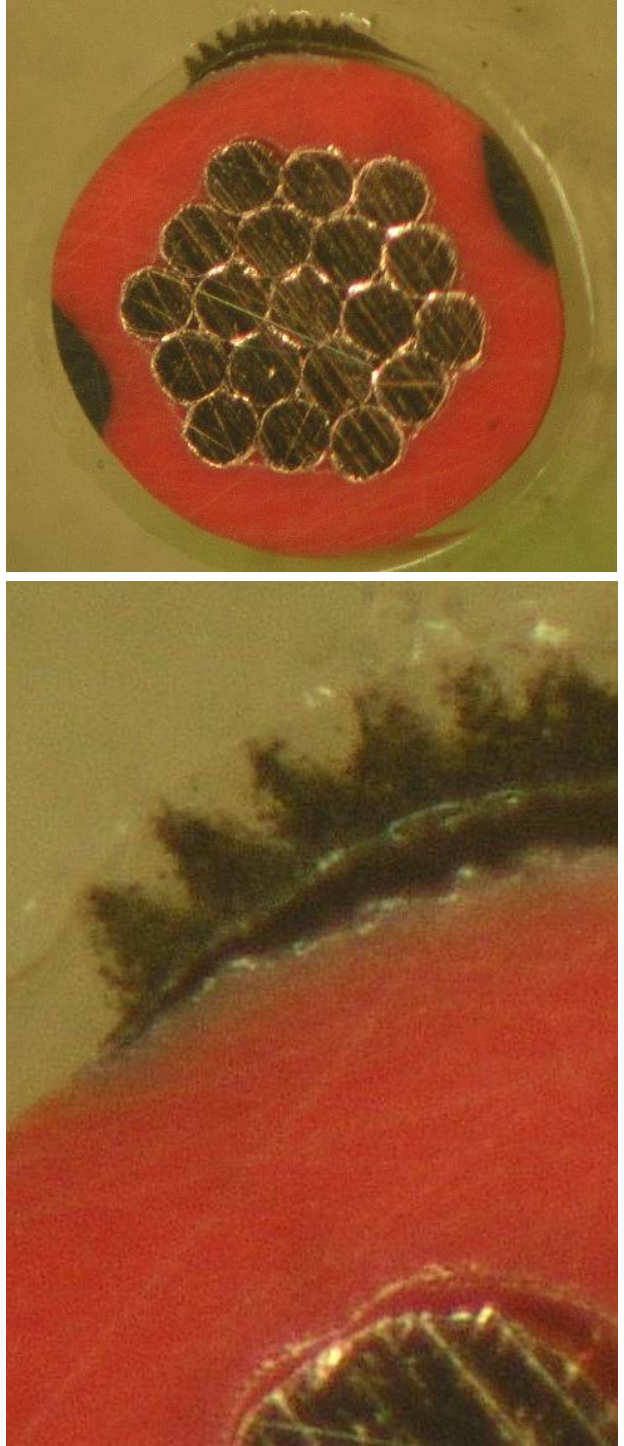

6. ábra. Sztereomikroszkóppal készitett makrofotók a keresztcsiszolatról. Jól látható az átlátszó bevonati réteg határa is a hö okozta szétválás miatt.

A behatolási mélységet a 7 . ábrán a szaggatott vonal jelöli. A lézersugár az átlátszó rétegben befelé szélesedő csatornákon hatolt be, és elválasztotta azt a piros színü szigetelőtől, amelyben már kicsi a behatolási mélysége. 

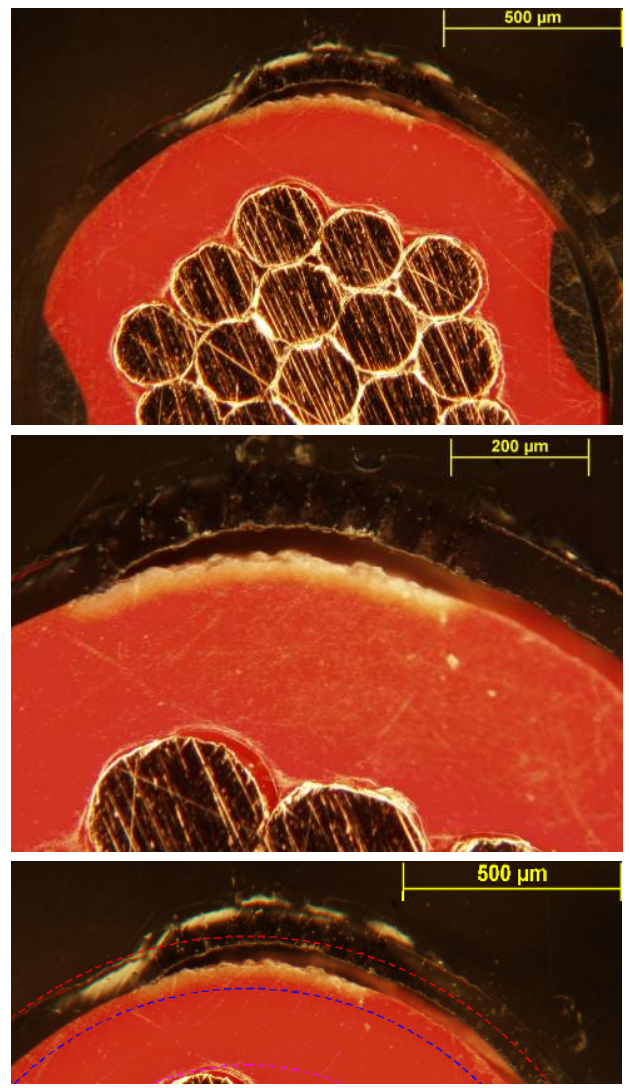

7. ábra. Fémmikroszkóppal készitett makrofotók a keresztcsiszolatról. A lézersugár behatolási mélysége 117 mikrométer

\subsection{A sárga + zöld színú vezeték vizsgálata}

A 8. ábrán látható a sárga és a zöld színü terület határára felvitt lézersugaras jelölés felületi képe, illetve a 9. ábrán a metallográfiai csiszolatról sztereomikroszkóppal készített kép. A behatolási mélységet a 10. ábrán szaggatott vonalak határolják a kétféle színü szigetelőanyagban egyaránt.

A lézersugár a sárga színü rétegben egyértelmüen észlelhetően mélyebbre hatolt be, mint a zöld színü szigetelésbe, de mindkét anyagnál jóval kisebb a behatolási mélység a többihez képest.
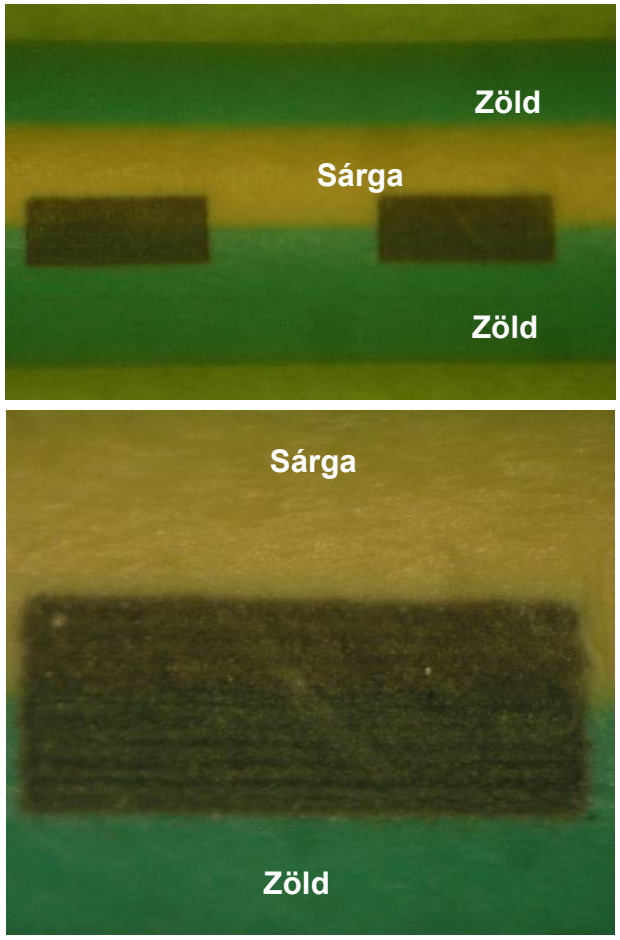

8. ábra. A 2×0,6 mm-es jelölés képe a szigetelés felületén

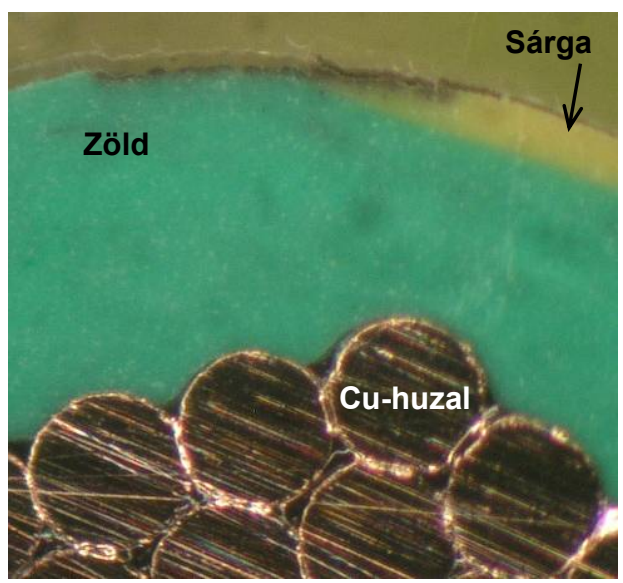

9. ábra. Sztereomikroszkóppal készitett kép a keresztcsiszolatról. Jól látható, hogy a zöld szinü müanyagban valamelyest kisebb mértékü a lézersugár által okozott látható elváltozás. 


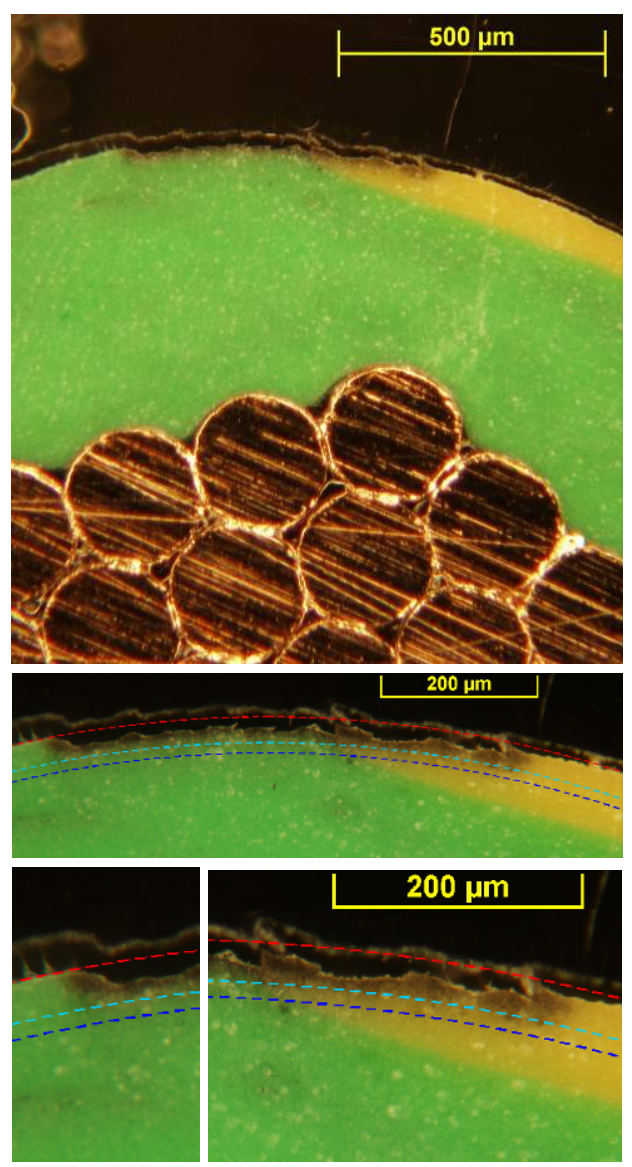

10. ábra. Fémmikroszkóppal készült kép a lézersugárral kezelt zóna keresztmetszeti csiszolatáról. A lézersugár behatolási mélysége a zöld anyagba 32, a sárga anyagba 45 mikrométer.

\subsection{A fekete színú vezeték vizsgálata}

A 11. ábrán látható a jelölés felületi és metszeti képe, a 12. ábrán a fémmikroszkóppal készített képek. A vezeték átmérője az összes közül a legkisebb (1,6 mm) volt, ezért itt már jelentősebb a téglalap alakú jelölési terület szélére és közepére beeső lézersugár beesési szögének eltérése.

A behatolást a 13. ábrán szaggatott vonal jelöli. A nagyobb felületi görbületváltozás ellenére a lézersugár viszonylag egyenletesen és kis mélységre hatolt be.
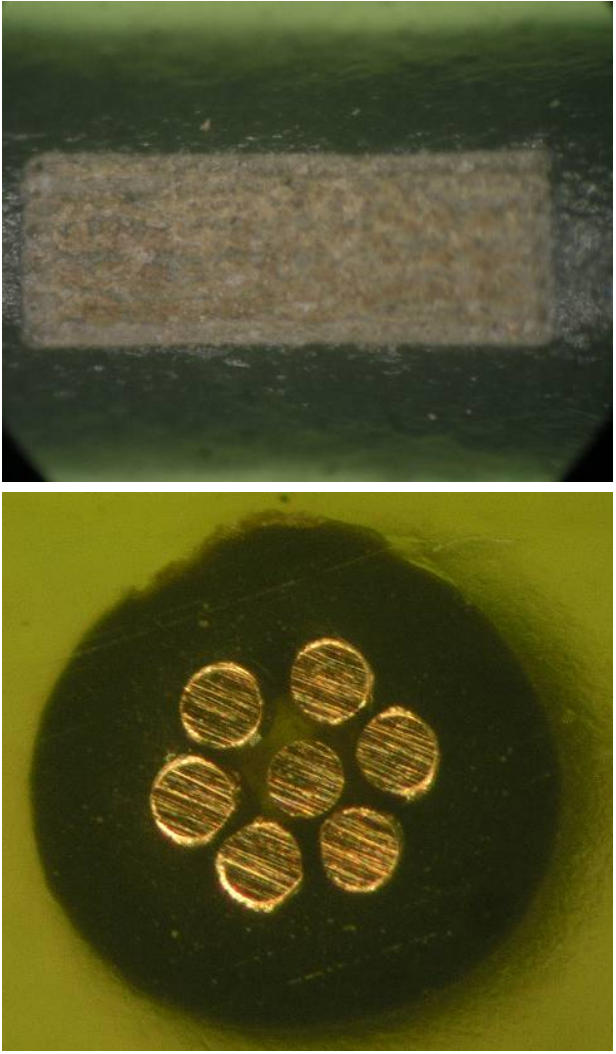

11. ábra. Makrofotók a felületröl és a keresztcsiszolatról
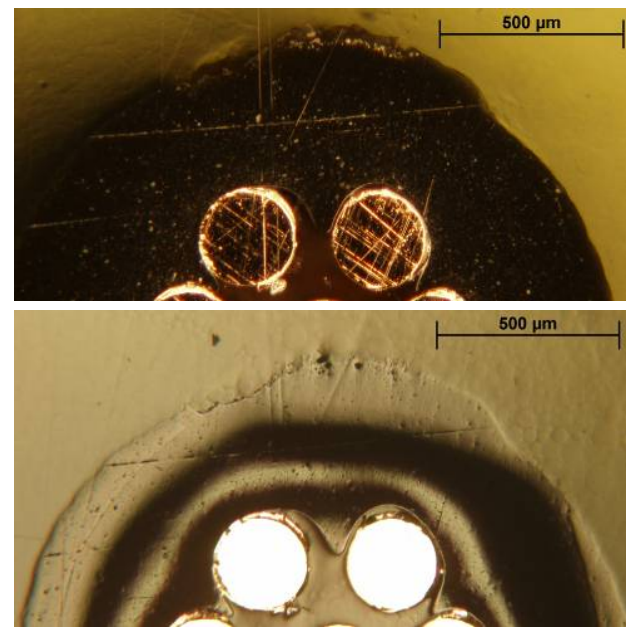

12. ábra. Világos és sötét látóteres kép a csiszolatról 


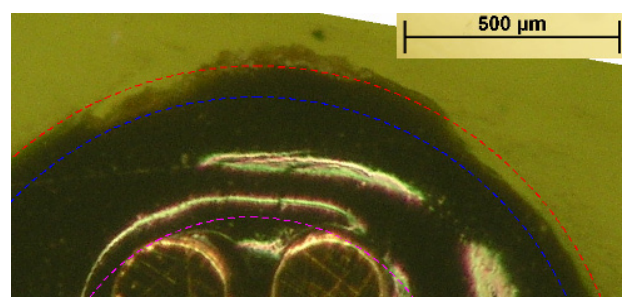

13. ábra. A lézersugárral kezelt zóna keresztcsiszolatán látható a lézersugár behatási mélysége: $72 \mu \mathrm{m}$

\subsection{Fekete színű, de eltérő összetételű szigetelés jelölése}

A 14. ábrán látható a lézersugaras jelölés felületi képe, illetve a keresztcsiszolatról készített képek. A behatolási mélységet a 14.d ábrán a két külső szaggatott vonal jelöli. A lézersugár viszonylag kis mélységre és egyenletesen hatol be.

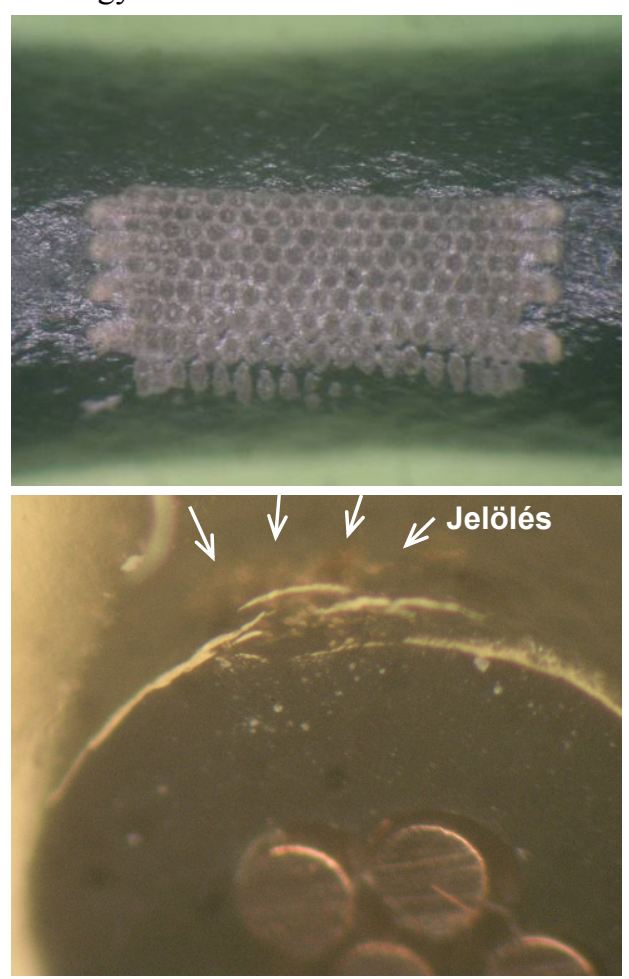

13. ábra. A jelölés sztereomikroszkóppal készitett képe a felületröl és $45^{\circ}$-os perspektívából
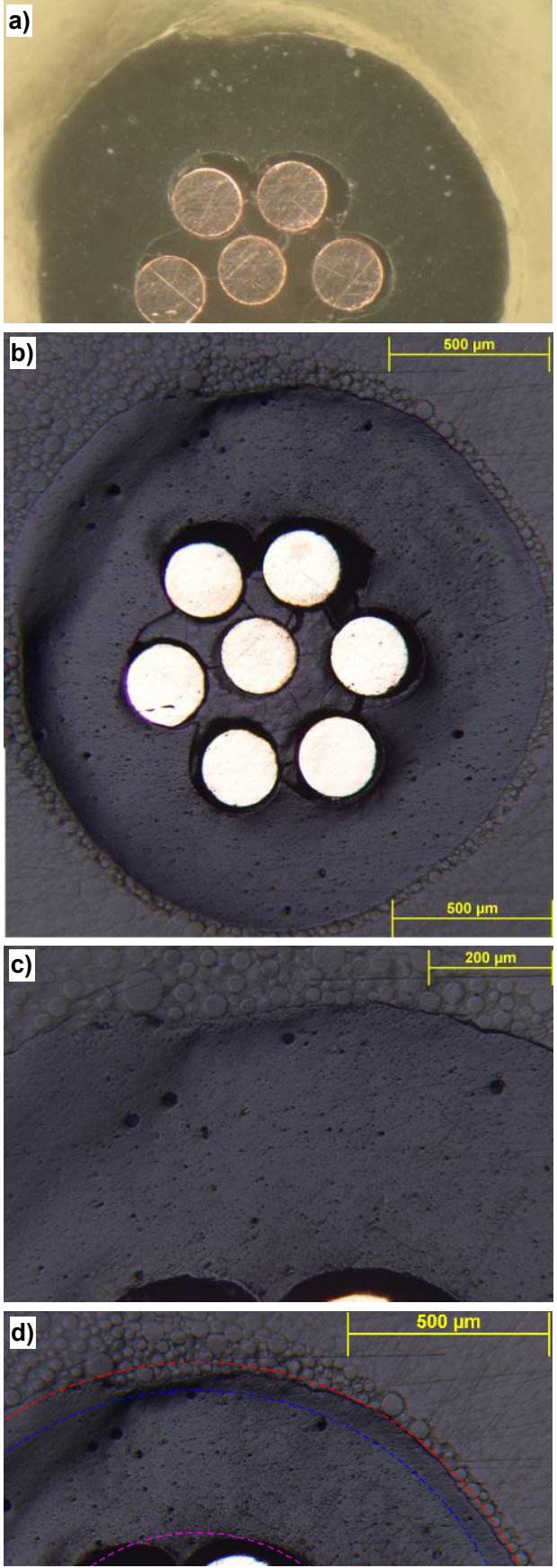

14. ábra. A vezeték keresztcsiszolatáról készitett képek. A lézersugár behatolási mélysége 66 mikrométer 


\section{7. Összefoglaló értékelés}

Elvégezve a különböző vastagságú és színü vezetékek szigetelésén található lézersugaras jelölések vizsgálatát, bemutattuk azt, hogy milyen változások mennek végbe a szigetelőanyagok felülete alatti zónában.

A lézersugaras jelölési mechanizmusok közül a hőszínezés technológiai tartományában kívántunk maradni, ami a 3.6. alfejezetben bemutatott vezeték kivételével minden esetben sikeresen meg is valósult; az említett kivétel esetében már a habosítási folyamatba is belecsúszott a technológia.

Mérésekkel meghatároztuk a lézersugár hatására elváltozást szenvedett zóna mélységét is, amely mérési adatokat az

1. táblázatban összegezünk.

1. táblázat. A jelölések behatási mélysége metrikus értékben és a szigetelés vastagságának százalékában megadva

\begin{tabular}{|c|c|r|r|}
\hline \multirow{2}{*}{ Sorsz. } & \multirow{2}{*}{ Szín } & \multicolumn{2}{|c|}{ Behatolás } \\
\cline { 3 - 4 } & & $\mu \mathrm{m}$ & \multicolumn{1}{c|}{$\%$} \\
\hline 1. & Sárga & 159 & 39,0 \\
\hline 2. & Piros & 88 & 21,2 \\
\hline 3. & Piros-fekete & 117 & 40,3 \\
\hline 4. & Zöld-sárga & 45 & 11,0 \\
\hline 5. & Zöld-sárga & 32 & 7,9 \\
\hline 6. & Fekete-H & 72 & 18,4 \\
\hline 7. & Fekete-R & 66 & 15,7 \\
\hline
\end{tabular}

A mérési eredmények alapján egyértelmüen levonható az a következtetés, hogy a lézersugaras jelölés behatolási mélysége jelentősen függ a vezetékek szigetelésének színétől és nyilvánvalóan az anyagától.
A technológiai változók szerepét nem elemeztük, mivel éppen az azok változatlansága esetén kapott eredmény az egyik fó kérdés a gyártási folyamatban. Természetesen a lézersugár behatolási mélysége tudatosan befolyásolható.

\section{Szakirodalmi hivatkozások}

[1] Cornish P: Laser beam absorption and mark depth of laser marked wires. Ref: ST0012, Spectrum Technologies Ltd. Bridgend, UK (1997)

[2] LATI Thermoplastics laser marking. LATI Industria Termoplastici S.p.A. Vedano Olona (2008)

[3] Bosman J: Processes and strategies for solid state $Q$-switch laser marking of polymers. Thesis Enschede, Velden, The Netherlands (2007)

[4] The ultraviolet (UV) laser marking performance of common aerospace wire and cable constructions. Abbreviated report, ST0057, Spectrum Technologies PLC, Bridgend, UK (2008)

[5] Zhang J, Williams C: Development of RoHS compliance colored ptfe tape for aerospace electric wire insulation. 60th IWCS Conference, Charlotte, USA, November 6-9, 2011, Paper 5-3.

[6] Varga B: Lézeres jelölés alkalmazása az elektronikai termékek azonositására. Elektronet: elektronikai informatikai szakfolyóirat, 16 (2007:2) 32-34.

\section{Köszönetnyilvánítás}

A szerzők közül Bitay Enikő kutatómunkáját a Magyar Tudományos Akadémia Domus ösztöndíjprogramja, valamint az A1-CT-TOK-12 Határon Túli Tapasztalt Oktató-kutatói Ösztöndíj támogatta. 